А, як доводить наш український досвід, чиновництву зазвичай байдужа доля української освіти і науки.

Українська освіта і наука, не отримуючи достатнього фінансування, на превеликий жаль, поступово вмирає. Курси ж, на зразок «Християнської етики» лише прискорять цей процес, перетворюючи освіту й науку щось на зразок «церковно-прихідських шкіл», а освітян і науковців - на «рабів Божих». Хто не розуміє цього - нехай ще раз уважно перечитає Статтю 35 Конституції України: «Церква і релігійні організації в Україні відокремлені від держави, а школа - від церкви».

Загальний контекст національно-культурного відродження українського народу не слід зводити винятково до відродження християнської моральності, а національно-культурний ренесанс українського народу - до християнізації України, оправославлення українців.

\title{
5.5 ПРАВОСЛАВ'Я УКРАЇНИ і НАЦІОНАЛЬНА БЕЗПЕКА
} (Олександр Саган). Науково-експертний матеріал для Служби безпеки України

Чи можна і чи потрібно розглядати події внутрішньоцерковного i міжцерковного православного життя України через призму національної безпеки? Наявними якими є больові точки у відносинах Української держави і православних Церков? Чи працює в Україні законодавство, яке регулює державно-церковні відносини і чи $є$ воно україноцентричним? Ці та інші питання були об'єктом розгляду експертного Круглого столу на тему: «Боротьба ідентичностей у православ ї України після «Революції гідності»: аспект національної безпеки», який відбувся в Києві 1 липня 2014 року. Організаторами заходу виступили Всеукраїнське товариство «Просвіта» імені Тараса Шевченка та Українська Асоціація релігієзнавців. У роботі Круглого столу, окрім представників організаторів цієї конференції, взяли участь експерти із УПЦ КП, УПЦ МП, всеукраїнського православного братства Андрія Первозванного УПЦ КП, науковці та громадські діячі з різних міст і регіонів країни, інші зацікавлені особи.

На Круглому столі було зазначено, що релігійний чинник довгий час залишався на периферії осмислення Україною своєї національної безпеки. Як фактор державної безпеки, власне релігійний чинник навіть не потрапив у концепцію (основи державної політики) 1997 року. В ній йшлося про духовність взагалі. І лише вже у концепції 2003 р., як і в Законі України «Про основи національної безпеки України» (2003р.) релігійний чинник виокремлюється із загальних «духовних цінностей», а останні потрапляють вже у розряд «національних інтересів». Стаття 7 цього закону вирізняє серед загроз національним інтересам і національній безпеці 
України «можливість виникнення конфліктів у сфері міжетнічних i міжконфесійних відносин, радикалізації та проявів екстремізму в діяльності деяких об‘єднань національних меншин та релігійних громад». Відтак, відповідно ст. 8, до основних напрямів державної політики 3 питань національної безпеки увійшло «забезпечення міжконфесійної стабільності та запобігання конфліктним загостренням на релігійній основі, недопущення протистояння різних церков, у тому числі щодо розподілу сфер впливу на території України». Проте названий Закон не врахував те, що загроза національній безпеці може надходити не лише від конфліктів на релігійній основі в Україні сущих конфесій, а й від пов'язання діяльності наявних у нас релігійних спільнот із зарубіжними релігійними центрами, щобільше, якщо такі виступають для них керівними духовними інституціями $\mathrm{i}$ водночас налаштовані вороже щодо суверенності України, іiі духовно-культурної самобутності. Стаття 10 Закону України «Про засади внутрішньої i зовнішньої політики» зобов'язує державні органи турбуватися про «відновлення повноцінного діалогу між представниками різних соціальних та етнічних груп, культур та релігійних конфесій», забезпечувати умови «для формування толерантного суспільства, гарантування свободи совісті та віросповідання».

Проте застосування статей згаданих вище законів аж ніяк не торкалося православ'я. Достатньо почитати видрукувані у нас монографії чи статті на тему держбезпеки у релігійній сфері, то в них можна зустріти матеріали про можливі загрози від «підступних» протестантів, харизматів, неорелігій, язичників та інших конфесій, навіть українських грекокатоликів. Але про загрозу Московського православ'я в Україні щодо їі суверенності, національного відроження практично ніхто із теоретиків служби безпеки чи діючих чиновників не писав. При цьому експертні ж записки та статті науковців-релігієзнавців, які застерігали від цієї небезпеки, відверто ігнорувалися. Відтак у цьому картина майже у прямій точності відображає систему захисту українських кордонів - переважна більшість сил і укріплень кордону були зосереджені на Заході країни, а удар ми отримали зі Сходу та з території анексованого Криму.

Тому постає закономірне питання: наскільки ретельно і повно щодо всіх діючих в Україні конфесійних спільнот застосовуються українськими силовими структурами, іншими відповідальними органами (наприклад, державним органом у справах релігій) норми чинного законодавства у відстоюванні національних інтересів у релігійній сфері? Адже коли клірик вчинив правопорушення проти держави та ії інтересів, то слід не бігти до речника УПЦ МП чи до їі предстоятеля, а вимагати пояснень від СБУ щодо бездіяльності цієї служби.

Більшість аналітиків - учасників Круглого столу - зійшлися на думці, що величезний потенціал можливостей відвернення порушень нашої національної безпеки державними органами, свідомо чи не свідомо, 
не задіюється. Особливо це виявляється тоді, коли йдеться не про кримінальні злочини (на них влада ще хоч якось реагує), а про правопорушення/злочини проти держави та нехтування нашими національними інтересами православними кліриками УПЦ МП, передусім y регіонах із домінуючим російськомовним православним населенням. Порушити питання зняття 3 реєстрації священослужителів причетних до рухів антимайдану і сепаратизму, підтримки бойовиків, а то й притягнення їх до кримінальної відповідальності за антидержавну діяльність.

Експертами було зазначено, що пострадянські державні інституції в Україні теоретично i надалі притримуються радянського принципу секуляризування державно-церковних відносин та звільнення усіх сфер, що знаходяться у компетенції держави, від регулятивно-санкціонуючої ролі релігії та Церкви. Проте на практиці, переживши класичний комплекс неофіта, багато чиновників на місцях фактично фаворитизували свої (прихожанами яких вони є) Церкви.

У більшості областей країни таким фаворитом стала саме Українська Православна Церква Московського Патріархату. Саме вона у часи президентства Л. Кучми мала негласну підтримку держави, навіть у Західній Україні, в отриманні повернутих державою храмів, дотацій i навіть в «освоєнні» заведених через різні хитросплетіння фінансових схем бюджетних коштів.

Таке фаворизитування, яке, на думку експертів, у багатьох регіонах присутнє й нині $є$ продовженням вже януковичівської політики щодо УПЦ МП, небезпечне передусім тим, що ця Церква виконує в Україні, окрім релігійної, й ідеологічну функцію. В умовах перманентної війни за державність, яка триває всі роки незалежності нашої країни, антиукраїнські ідеологічні заготовки, політичні установки Партії регіонів і комуністів вносяться в голови і серця вірних не лише з екрана телевізора, а й майже повсемісно 3 амвона означеної Церкви. Логічним результатом діяльності москвофільських кліриків i єпархів стало формування антиукраїнських настроїв у вірних УПЦ МП, що особливо гостро проявилося у Криму, на Півдні та Сході України під час постмайданівської кризи ідентичностей на фоні російської агресії.

Характеристика зовнішніх загроз, які виокремлюються фахівцями національної безпеки у сфері релігії, зводиться до наступних пунктів:

1. Розробка механізму втручання у внутрішні справи України.

2. Діяльність із розпалювання міжнаціональних, міжконфесійних та міжцерковних конфліктів.

3. Обгрунтування й підтримка автономістських ідей i сепаратистських сил частини населення певних регіонів України.

4. Використання релігійних організацій спецслужбами іноземних держав для проведення розвідувально-підривної діяльності.

5. Співпраця релігійних організацій (усвідомлена чи не усідомлена) iз екстремістськими угрупованнями 3 метою провокування акцій 
громадської непокори, масових заворушень, антиукраїнських і проросійських хресних ходів, терористичної та іншої протиправної діяльності.

6. Поширення деструктивних ідеологій щодо суверенності України, ii національно-духовного віродження за допомогою релігійного навчання та діяльності релігійних організацій.

Як бачимо, значна частина кліриків та ієрархії парафій (єпархій) УПЦ МП, особливо провідники пропагованого i обстоюваного Московським Патріархом Кирилом т.зв. «русского міра» та російським президентом феномену «Новоросії», у своїй діяльності не зуміли уникнути багатьох із задекларованих вище пунктів загроз. Відтак вони чітко підпадають під характеристику осіб/інституцій, які несуть загрозу національним інтересам України, іiі суверенізації як незалежної держави. Вони є співучасниками тієї крадіжки української історії X-XVII століть, до якої вдається Московська Патріархія, приписуючи собі події цього періоду церковного життя Київської митрополії, яка належала тоді до Константинопольського Патріархату. Власне Українським Проавославним Церквам вдатися до перегляду нав'язаного їм Російською Церквою календаря свят, вилучивши 3 нього ті, які працюють на освячення імперської політики Московії. Чи понесли клірики цієї УПЦ МП відповідні до чинного законодавства покарання за свої по суті антидержавні дії? Hi. Експерти роками пишуть листи в СБУ про те, що у регіональних 3МI, які видруковують або патронують ієрархи УПЦ МП (напр., газети «Мир», «Триединая Русь», «Начало», «Новороссийский курьер» та ін.), друкуються статті, що становлять загрозу національній безпеці та інтересам України. Зокрема містять наклепи та відверту брехню щодо українських світських та релігійних діячів, викривлено і однобоко, 3 антиукраїнських позицій подають перебіг останніх подій у Донецькій та Луганській областях, в Криму, свідомо перекручують факти 3 історії України, розвитку тут православ'я, всіляко пропагується російський монархізм, події і діячів московської звитяги тощо. Не закриті для доступу в Україні й російські церковні ресурси «Русь державная», «Радонеж», «Православная Москва» та ін., які відійшли від аполітичної просвітницької позиції й активно зайнялися явно антиукраїнською пропагандою.

Проте навіть жодної відповіді (не те що визначеної чинним законодавством дії) щодо експертних листів про загрози 3 боку т.зв. «московського православ'я» експертне середовище від державних структур так і не отримало. Натомість із СБУ приходять на експертизу матеріали щодо харизматичних церков, мусульманської літератури, свідків Сгови, рідновірів тощо. Такий стан справ, на думку експертів, свідчить і про негласну підтримку відповідальними за «релігійну безпеку» співробітниками СБУ і прокуратури антиукраїнських настроїв в УПЦ МП (i позиція співробітників СБУ у анексованому Криму, Донецькій та Луганській областях повністю підтверджує цей висновок), а також про 
намагання спецслужб i надалі працювати із церковними лідерами за рахунок маніпулювання накопиченим компроматом. Яскравим прикладом цього є т.зв. справа митрополита Олександра Драбинки. Справа закрита, проте ніхто із силовиків за ï ініціювання так не поніс покарання. Українським спецслужбам слід відмовлятися від спадщини КДБ i переходити від «платформи компромату» на «платформу закону» у роботі із Церквами.

Відтак, на думку експертів, в умовах фактично неоголошеної війни, центральний орган виконавчої влади у справах релігій та відповідні державні інституції й служби (зокрема Прокуратура i СБУ) мали б привести у відповідність до чинного законодавства діяльність тих релігійних організацій, які радикалізують ситуацію, діють антиукраїнськи, сприяють у різноманітний спосіб агресорові та терористам. Особливо це стосується ідеологічної роботи.

Інше питання, яке стало об‘єктом розгляду учасників Круглого столу, було питання представлення українських Церков у міжнародних органах, зокрема при європейських структурах, та у міжнародних церковних організаціях. Адже не є секретом, що багато у чому суверенітет Церков підтверджується/забезпечується саме самостійною участю українських конфесійних спільнот у міжнародних церковних організаціях. Експерти наголошують на абсурдності ситуації, коли православні Церкви України у міжнародних інституціях репрезентують представники Московської патріархії - адже у багатьох питаннях позиції України та Російської Федерації (де-факто державною Церквою якої є Московський патріархат) кардинально відрізняються. Представництво власне українських спільнот в міжнародних міжконфесійних інституціях - це засвідчення суверенності України як держави. Його немає. До речі, цей аргумент був прийнятий учасниками також як один із важливих чинників необхідності конституювання в Україні Помісної православної Церкви.

Учасники Круглого столу визнали Московський Патріархат і зокрема його очільника Кирила співучасниками фашистської політики Путіна, його загарбницької діяльності щодо України. Вони вважають, що Українські Православні Церкви аж ніяк не можуть бути складовими цієї антиукраїнської спільноти i мали б вирішити питання свого нового церковного буття. Відтак будь-які візити Патріаврха Кирила в Україну мають узгоджуватися з Українською владою і взагалі не є бажаними i необхідними. Вони будуть розпалювати у нас міжцерковне протистояння. Варто вдатися до громадського засудження мовчанки щодо московського агоесора не тільки російського патріарха Кирила, а й тих архієреїв з УПЦ МП, які виявили свою однодумність із своїм московським патроном.

Експерти зазначили, що актуальним для України $є$ також питання законодавчого оформлення особливого статусу окремих Церков (або їх об‘єднань). Цей статус в окремих Церков вже наявний де-факто. Проте без його осмислення складно у законодавчому полі вирішувати інші 
стратегічні питання, що давно вже стоять на порядку денному у державноцерковних відносинах. Наприклад, запровадження інституту капеланства у силових i пенітенціарних структурах країни, відкриття релігійними організаціями загальноосвітніх шкіл та ВУЗів, ліцензування державою теології/богослов'я як навчальних дисциплін тощо. Більшість із цих питань вже вирішуються завдяки домовленостям найкрупніших Церков. Проте, вирішуючи завдяки різноманітним суб'єктивним чинникам ці та багато інших питань, релігійні інституції фактично не несуть жодної юридичної/моральної відповідальності перед державою/суспільством за наслідки своєї роботи. В такий спосіб стала можливою наявність в Україні кліриків, віруючих, біляцерковних громадських організацій, які ведуть антидержавну пропаганду i агітацію, виховують своїх вірних в дусі ворожості до інших релігійних спільнот та політичних (перш за все проукраїнських) переконань тощо. Антиукраїнського сенсу біляцерковні спільноти найбільше кучкуються біля всеукраїнського (Києво-Печерська Лавра) і єпархіальних центрів УПЦ МП. Всіляко відгороджуючись від них, московсько- православні центри водночас дозволяють їм зосереджувати свою діяльність саме в їх офісних приміщеннях. Так, всі невідомо ким профінансовані антиукраїнські, російсько-монархічні «хресні ходи» православних братств УПЦ МП майже щотижня 3 портретами/іконами російського царя Миколи II, монархічними гаслами i московськими символами починаються і завершуються в Києво-Печерському монастирі. Заяви/вимоги цих заходів зорієнтовані часто проти суверенності України, містять фальсифікацію історії українського народу, зорієнетовані на розпалювання міжконфесійного і міжцерковного протистояння.

На Круглому столі відзначалася та тенденційність i некомпетентність, яка спостерігається в інтерпретаціях стану сучасного Православ'я України, його можливих перспектив на сторінках багатьох ЗМI. Навть така проукраїнська газета як «День» дозволила друкувати статті москвофільського релігієзнавця, який, підспівуючи і підслуговуючи Московському Патріархату, глузливо пропонує Святійшому Філарету найбільш знаній постаті сучасного власне Українського Православ'я i активного його захисника відмовитися від статусу Патріарха УПЦ КП з тим, щоб на об'єднавчому архієрейському соборі двох церков - МП та КП - обрати єдиного Патріарха. Зрозуміло, від якої Церкви і 3 якими орієнтаціями цей Патріарх буде обраний. Водночас ця ж газета видрукувала статті того ж автора, в яких він піддає брехливому знеславленню провідника власне українофільської лінії в УПЦ МП митрополита Олександра Драбинка, звинувачуючи його ледь не в сприянні захворюванню і зрештою смерті Предстоятеля УПЦ МП Володимира, у різних деструктивах всередині означеної православної спільноти.

Складні процеси самоідентифікації, які відбуваються нині в УПЦ МП, можуть мати, на думку експертів, далеко йдучі наслідки не лише для цієї Церкви, але й країни в цілому. Адже за умови перекриття прямого 
ідеологічного каналу впливу промосковської пропаганди, відцентрові сепаратистські тенденції на Сході та Півдні України підуть на спад. Але цю пропаганду у свій спосіб перебирає на себе у багатьох випадках клір УПЦ МП. І це не дивно. Не слід забувати, що Московський Патріархат, якому підпорядкована УПЦ МП, є фактично державною Церквою Росії: патріарх МП є громадянином цієї країни, зареєстрована вона в Мінюсті РФ, оперує державною мовою Росії, має своє представництво у всіх силових міністерствах цієї країни. Саме тому й в Україні Церква Московського Патріархату служить тій же державі, тобто Pociï.

Недавній голова синодального відділу із зв'язків Московського Патріархату з громадськістю Всеволод Чаплін прямо заявляс: «Потрібно подумати сьогодні про потужну військову присутність Росії у всіх регіонах, де люди просять захисту від Помаранчевих експериментів, від різних «кольорових революцій». Навіть якщо Росії знадобиться, то росіяни братимуть участь у бойових діях. Армії потрібно нарешті дати справжню роботу». Виступаючи свого часу на Всесвітньому російському народному соборі владика з УПЦ МП Августин Маркевич, який, до речі, від УПЦ МП опікується в Україні ії силовими структурами, наголосив: «Ми очікуємо кроків з боку Росії як загін, що чекає команди кинутися у бій... Єдине, що нас надихає, то це те, що ми віримо в Росію». Незасудження МосковськоПравославною Церквою України російського загарбника певне і $є$ виявом цієї віри в Росію, а в можливій перспективі проислужництва їй. Та хіба можуть владики неукраїнської національності виявляти свою приязнь до саме українського національного відродження, входження України не в Митний Союз, а в Свросоюз? Скоріше що ні.

Чи можлива нині зміна статусу УПЦ МП в Україні або, точніше, набуття нею визначеної канонами автономії чи автокефалії? Відповідь на це питання залежить від багатьох чинників. Зокрема від активності біляцерковних організацій та політичних партій, зорієнтованої на вирішення цього питання, а також від того, наскільки українські чиновники нарешті почнуть виконувати чинне законодавство (нівелюють антиукраїнську пропаганду i т. п.). Важливою буде й позиція проукраїнських громадських організацій при їх оцінці розвитку міжцерковних та внутрішньоцерковних процесів у православ 'ї. Можлииво варто перереєструвати Українську ПЦ в ііі дійсній назві, проголошеній фашистом Путіним - «Русская Православная Церковь в Украине».

У розвиток цих думок на Круглому столі було наголошено, що в Україні (на відміну, зокрема, від Росії) державні інституції практично завжди нехтували той факт, що Церква відіграє важливу роль у державному будівництві (історія свідчить, що країни втрачали отриману/завойовану політичну незалежність, якщо вони не підкріпляли їі незалежністю релігійною). В Україні релігійний фактор, свідомо це чи не усвідомлено, враховується за т.зв. «залишковим» принципом. 
Проголошений ще в роки президентсва Л. Кравчука принцип «Незалежній державі - незалежну Церкву» з роками був зневільований. Одначе це було і $є$ принциповою помилкою. А між тим, як знаємо, перебирання Церквою в Україні в роки іï бездержавницької історії на себе саме державницьких функцій послужило підгрунтям національного збереження українства.

При аналізі подій у нинішній УПЦ МП учасниками Круглого столу було наголошено також на тому, що ця Церква перебуває на порозі значних змін. Проте українське суспільство не відчуває найменшого бажання очільників цієї Церкви, зокрема більшості їі Синоду і керівників єпархій, до очищення чи покаяння за тісну співпрацю із антинародним i наскрізь корумпованим режимом, який вибудував, в т.ч. і не без допомоги УПЦ МП, В. Янукович. Дивним виглядає уникання священноначалієм УПЦ МП персонального засудження (покарання) тих із кліриків та церковних активістів, які відкрито співпрацюють нині із терористами i сепаратистами. Хоча УПЦ МП оперативно реагує на будь-які інші так звані провини, а особливо на контакти своїх кліриків із священиками УПЦ КП чи УАПЦ. Можливо так як суспільно-державна сфера в Україні має пройти свою люстрацію, так вона мала б проявитися і в церковній сфері, де водночас наявні ще й ганебні як для священнослужителів та ієрархів вияви корупції

Не почуло суспільство «голосу Московсько-Православної Церкви» $\mathrm{i}$ у питаннях визволення із полону терористів українських бійців, журналістів, священиків та віруючих протестантських Церков. А, як знаємо, Церкви у роки Другої світової війни формували за свої кошти цілі танкові колони і навіть ескадрилії. До подібних дій вдаються в Україні нині і Церква Київського Патріархату, і Греко-Католитцька, але не УПЦ МП. Вона включена у процес підтримки армії лише на рівні приватних ініціатив окремих єпископів та священиків. Складається враження, що керівництво УПЦ МП надто обережне у своїй позиції із засудження агресора і обмежується закликами до миру, які ми чули ще 3 часу Майдану. На Донбасі ллється кров, а митрополити УПЦ МП Донецької та Луганської єпархій як в рота води набрали. Не чуємо засудження ними варварства бойовиків. Тут вони в унісон глаголять iз речниками Партії регіоналів (а це нині так званий Опозиційний блок) про мир. Але ж всі ми розуміємо, що «мир» призведе до узаконення на донецьких теренах самопроголошених так званих «народних республік», непокараності терористів, спричинить $3^{6} я в$ в регіоні аналогів Придністров'я. Тут варто нагадати мудрий висновок Івана Франка: «У час війни та бою / Ти зовеш до супокою, / Зрадник або трус єси...».

3 цих питань, що було відзначено на Круглому столі, явно проукраїнську позицію зайняла Церква Київського Патріархату i ii Предстоятель - патріарх Філарет. Без якоїсь дипломатії вона засудила Московського агресора i його фаворизування 3 боку Російської Православної Церкви. УПЦ КП чітко заявила, що вона вестиме 
перемовини з УПЦ МП щодо усунення розколу в Православ “̈ України лише за умови відсторонення іiі від підпорядкування Московському Патріархату. Проте для учасників Столу дещо незрозумілою виявилася позиція УАПЦ, яка в особі свого єпископа Володимира Черпака постійно була присутня на Євромайдані і водночас виявляє незрозумілу мовчанку в оцінках Московського агресора, не прийняла запрошення на наш Круглий стіл. В Україні в такій ситуації говорять: мовчанка - ознака згоди.

Українське суспільство також очікує більш дієвих кроків кліру УПЦ МП у відмежуванні себе від антиукраїнської та шовіністичної за своєю суттю ідеї «русского міра», яку активно насаджує в Україні як Московська патріархія, так і світська російська влада (у формі боротьби за т.зв. права «русскоязычных» і т.п. інші міфічних ініціатив). Із схваленням на Столі був сприйнятий видрук Відділенням релігієзнавства Інституту філософії НАНУ колективної праці «Русский мир» патріарха Кирила не для Украӥни». Зажадано від науковців нових праць 3 розвінчуванням проросійської позиції з боку єпископату, кліру i різноманіття біляправославних спільнот, преси єпархій УПЦ.

Одним із найдієвіших способів врегулювати ситуацію в православ “ї в Україні експерти вважають надання населенню правдивої інформації як про українську історію та розвиток Церков, так і про нинішню ситуацію у державно-церковних відносинах. Держава повинна відродити систему просвіти населення, більш повно використовувати можливості товариства «Знання». Не повністю, на думку присутніх, використовуються структурами громадянського суспільства, україноцентричними Церквами саме можливості українських ЗМІ у поширенні як ідеї Помісності православ'я, так і протидії «русскому міру» патріарха Кирила, іншим подібним промосковським ідеологемам.

Зважаючи на те, що така важлива історична подія, як хрещення України-Руси, не має прямого відношення до інституйованої лише в 1589 році Російської Православної Церкви, а також враховуючи нинішню політичну ситуацію в Україні, військову та інформаційну агресію Росії щодо нашої країни, учасники Круглого столу наголосили на недоречності приїзду на українські терени 3 цієї нагоди Патріарха Московського Кирила. Московська Церква краде українсько-православну історію. 3 таким правом як вона включає до своєї історії «Володимирове хрещення», вона могла б прибрати для себе і проголошення ще в четвертому столітті імператором Костянтином християнства державною релігією Риму. Між тим Московський патріархат використовує подію 988 року для обгрунтування права Московії на всю так звану « історичну Русь», оправдання загарбницьких посягань Росії на українські терени. Науковцям-історикам варто попрацювати над тим, щоб засвідчити самобутність саме Українського Православ'я, його відмінність від Московського, а відтак право українців на свою Помісну Православну Церкву. 
Відтак, підтримавши загалом заяву Міністерства культури України, озвучену керівником Департаменту у справах релігій та національностей В. Юшкевичем, щодо небажаності приїзду глави Руської ПЦ в Україну на відзначення річниці хрещення Київської Русі, експерти наголосили на неповноті подібних заяв (по формі й юридичному обгрунтуванню). Насамперед мало йтися про приведення тепер і в наступному порядку здійснення подібних візитів до чинного українського законодавства. Адже жодного разу центральний орган влади у галузі державно-церковних відносин не погоджував до цього року подібні візити Кирила. Внаслідок чого, вважають експерти, й стали можливими факти, коли разом iз Московським патріархом чи у супроводі різноманітних «дарів» і різних «священних реліквій», в Україну безперешкодно в“їжджали особи, які згодом організовували тут терористичну роботу. Класичним прикладом цього $€$ т.зв. Гіркін-Стрілок, який використав свій супровід так званих «дарів волхвів» явно 3 шпигунською метою. А про скількох таких «гіркіних» ми не знаємо? Зрештою Патріарху варто було б нагадати, що річниця Хрещення Київської Русі не є фрагментом історії Московського Православ'я.

Експертами було наголошено на важливості для Українського народу Києво-Печерської і Почаївської Лавр як культурно-історичних святинь. А відтак говорилося про необхідність застосування державними органами норм чинного законодавства 3 метою протидії перетворенню їх на антиукраїнські осередки, центри продукування напруги, концентрації прихильників «русского міра» тощо. Лаври мають служити Україні, а не ворогам іiі суверенності, національної духовності. Питання належності їх якійсь одній із наявних в Україні Церков можна буде вирішити лише після їх об'єднання. Висловлювалася думка про доцільність мати в Києві прелставництво Константинопольського Патріархату, який є Церквоюматір“ю для православних Церков України і який на цій підставі має повне право (і лише він!) на вирішення питання автокефальності Української Церкви.

Що запропоновано експертами Круглого столу державним органам:

1. Провести низку заходів із захисту національних інтересів й безпеки України в інформаційно-релігійній сфері. Зазначено, що особливістю української інформаційної війни мало б бути не копіювання російських масових фальсифікацій фактів та пропагування брехні «во благо», а адекватні свідчення, грунтовані на історичних і реальних сьогоденних даних. Можливим може бути навіть закриття тих ЗМІ Московсько-Православної Церкви i iï біляцерковних структур, які систематично займаються антидержавною пропагандою, розпалюванням міжнаціональної i міжцерковної ворожнечі. Важливим $\epsilon$ також спростування науковцями тих фальшивих інформацій, які подають щодо стану в Православ“ї України в газетних масовках їх журналісти. Враховуючи часту проросійську зорієнтованість кліру УПЦ МП, вважати 
неможливим залучення його до проведення занять 3 християнської етики в загальноосвітніх школах.

2. Докорінна, але у межах чинного законодавства, зміна ставлення державних органів, які відповідають за державний інтерес і безпеку, до антиукраїнської та екстремістської діяльності тих кліриків та віруючих, православних братств i козацтва, які підтримують і пропагують т.зв. промосковське «політичне православ'я», «русскій мір» та подібні ідеологеми (не говорячи вже збройну боротьбу проти держави та сепаратистські заклики). Поштовхом до такої діяльності має бути активність структур громадянського суспільства та експертного середовища, а також активізація ЗМІ - як світських, так і церковних щодо висвітлення ролі московсько-православного кліру і братств у сепаратистській та підривній діяльності в Україні. Наслідком такої зміни ставлення має бути позбавлення тих релігійних організацій, навіть Церков чи біля них сущих братств, які порушують чинне законодавство, реєстрації та статусу «релігійної», із всіма витікаючими звідси висновками, в т.ч. й економічного плану (оподаткування, пільги тощо). СБУ вивчити наявну можливість залишення присутності Московського КДБ в структурах УПЦ МП.

3. Максимально сприяти прискоренню прийняттю ВР закону «Про Концепцію державно-церковних стосунків». Сформована вже Всеукраїнською Радою Церков та релігійних організацій за підтримки Центру ім. О. Разумкова ця Концепція могла б довести Церквам та релігійним організаціям незмінність курсу держави на гарантування прав та свобод вірних, свободи віросповідань і власне релігійної діяльності. Нині, під час нових викликів демократії, символічний крок прийняття Концепції став би імпульсом до ще більш конструктивної підтримки всіма основними Церквами та релігійними організаціями Української держави, розробки на ії основі нового Закону про свободу совісті.

4. Необхідно активніше пропагувати у фахових та публіцистичних ЗМІ ідеї побудови демократичної моделі «держава - церква громадянське суспільство», яка виключала б будь-яке фаворизування владою тих чи інших конфесійних спільнот, рівне їі ставлення до всіх їх офіційно зареєсторованих. Саме при такій моделі можливий найбільш ефективний розвиток українського суспільства, що й показує нині діяльність Всеукраїнської Ради Церков i релігійних органгізацій. Враховуючи необхідність забезпечення інформаційної безпеки, провести семінар журналістів ЗМІ, які подають матеріали на своїх шпальтах про роль і стан Православ'я України.

5. Зважаючи на ту роль, яку відіграє православна Церква в духовній національній єдності та утвердженні української державності, держава повинна вжити усіх законних (в т.ч. дипломатичних) заходів для утвердження Помісної Української православної Церкви. Потрібне також усвідомлення того, що успіх справи конституювання Помісної 
православної Церкви в Україні залежить передусім не від позиції ієрархів УПЦ МП - багато із них надто залежні від московського бачення історії православ'я в Україні, а відтак не уявляють УПЦ поза Московською патріархією. Необхідно формувати різними засобами переконання передусім у пересічних віруючих національну потребу повернути у Церкву соборноправність та через соборну думку переконувати весь православний клір (насамперед єпископат) підтримати автокефальні прагнення українців. Враховуючи наявність на теренах України серед іiі населення 20\% росіян і десь такої ж кількості зросійщених, які ніколи не сприймуть власне Українське Православ'я, вважати можливим підтримати утворення i діяльність на теренах України, окрім Української Автокефальної Православної Церкви, екзархату Російської ПЦ.

6. Українській науці варото визначитися в історичній безпеці України і вдатися до захисту ії історичного простору від привласнення його росіянами. Визначитися в понятті історичної правонаступниці. Зокрема важливо науково довести, що подія Хрещення Київської Русі, історія православ'я на українських тереннах X-XVII століть не належить Російській Православній Церкві. Активніше слід пропагувати особливості власне Українського Православ'я, його відмінність від інших православних автокефалій, відродження в посталих і сформованих у XX столітті автокефальних православних спільнотах. Провести в другій половині 2014 року на базі Відділення релігієзнавства ІФ НАНУ наукову конференцію «Православ'я України в його історії і сьогоденні».

Відтак Круглим столом актуалізується необхідність підтримки тих ініціатив ієрархії та вірних всіх православних Церков, а також громадськості, які сприятимуть конституюванню Помісної православної Церкви в Україні. Зокрема, незаслужено забуті ініціативи із проведення Всеукраїнських церковно-громадських форумів «За Українську Помісну Православну Церкву» (останній відбувся 12 червня 2007 р.), а також відповідної тематичної зорієнтованості інформаційно-просвітницька робота.

НАУКОВО-ЕКСПЕРТНИЙ МАТЕРІАЛ СХВАЛЕНИЙ ВЧЕНОЮ РАДОЮ ВІДДІЛЕННЯ РЕЛІГІЄЗНАВСТВА ІНСТИТУТУ ФІЛОСОФІЇ ІМ. Г. С. СКОВОРОДИ НАН УКРАЇНИ

\section{6 ПРО ЗМІСТ І БОГОСЛУЖБОВЕ ЗПАСТОСУВАННЯ ЛІТЕРАТУРИ СВІДКІВ СГОВИ. Науково-експертний матеріал, підготовлений професором П. Яроцьким}

За дорученням Національної академії наук України (22.10.2013, ғ 2171) відділ історії релігії і практичного релігієзнавства Відділення релігієзнавства Інституту філософії імені Г. С. Сковороди НАН України 